\title{
Pallidal deep brain stimulation: an effective treatment in Chinese patients with tardive dystonia
}

\author{
Peter YM Woo, Danny TM Chan, XL Zhu, Jonas HM Yeung, Anne YY Chan, Angie CW Au, KM Cheng, \\ KY Lau, YK Wing, Vincent CT Mok, WS Poon *
}

\footnotetext{
- A video showing the treatment outcome of a patient with refractory tardive dystonia by pallidal deep brain stimulation is available at <www.hkmj.org>
}

\section{A B S T R A C T}

Tardive dystonia is an iatrogenic complication of dopamine receptor antagonist medication such as first-generation antipsychotics. It occurs in up to $2 \%$ of patients and only $10 \%$ recover after stopping medication. Deep brain stimulation for primary dystonia has proven to be effective and its application for secondary dystonias is gaining acceptance. We report our experience in treating three ethnic Chinese schizophrenia patients with severe medically refractory tardive dystonia by globus pallidus internus deep brain stimulation. Preoperatively, all required assistance with essential activities of daily living and two were bed-bound. The mean Burke-Fahn-Marsden Dystonia Rating Scale score was 61 (range, 44-80) and mean Global Dystonia Rating Scale score was 47 (range, 40-52). No procedure-related complications were encountered. By 3 months all could return to unassisted living and walk with support with a mean of $77 \%$ and $66 \%$ improvement in the Burke-Fahn-Marsden Dystonia Rating Scale and Global Dystonia Rating Scale scores, respectively. Quality-of-life assessment performed for two patients using the EuroQol-5 dimensions visual analogue scale showed a mean improvement of $86 \%$ at 3 months. On clinical follow-up, the effect was well maintained for a period of 3 to 10 years. Pallidal deep brain stimulation is a safe and highly effective form of symptomatic treatment for patients with medically refractory tardive dystonia.

Hong Kong Med J 2014;20:455-9

DOI: 10.12809/hkmj134082

${ }^{1}$ PYM Woo, MB, BS, FRCS (Edin)

DTM Chan, MB, ChB, FRCS (Edin)

${ }^{1}$ XL Zhu, BMed (Jinan), FRCS (Edin)

1 JHM Yeung, MB, ChB, FRCP (London)

${ }^{1}$ AYY Chan, MB, ChB, MRCP

ACW Au, MB, ChB

${ }^{2}$ KM Cheng, MRCPsych, FHKAM (Psychiatry)

${ }^{1} \mathrm{KY}$ Lau, MSc

${ }^{3}$ YK Wing, FRCPsych, FHKAM (Psychiatry)

${ }^{1}$ VCT Mok, MB, BS, FRCP (Edin)

${ }^{1}$ WS Poon *, MB, ChB, FRCS (Edin)

Movement Disorder Group, Division of Neurosurgery, Department of Surgery and Department of Medicine and Therapeutics, Prince of Wales Hospital, The Chinese University of Hong Kong, Hong Kong

2 Department of General Adult Psychiatry, Castle Peak Hospital, Hong Kong

Department of Psychiatry, Prince of Wales Hospital, The Chinese University of Hong Kong, Hong Kong

* Corresponding author: wpoon@cuhk.edu.hk

\section{Introduction}

Tardive dystonia (TD) is an iatrogenic extrapyramidal movement disorder caused by the use of dopamine receptor antagonists (DRAs). Antipsychotic medications, especially belonging to the first-generation class, are typically responsible for the condition. ${ }^{1}$ The reported prevalence of this adverse drug reaction among adults varies from $1 \%$ to $2 \%$ and only $10 \%$ of patients recover after medication termination. ${ }^{2}$ The latency of onset could range from several days to 20 years. ${ }^{3}$

Initial management strategies include withdrawal of the offending antipsychotic, switching to a second-generation antipsychotic such as clozapine, and suppressive therapies such as benzodiazepines or tetrabenazine, but none has demonstrable efficacy. ${ }^{3}$ In recent years deep brain stimulation (DBS) of the globus pallidus interna (GPi) has proven to be effective for secondary dystonias such as TD. ${ }^{4-7}$ We report our experience with using DBS for treating three young ethnic Chinese patients with severe TD refractory to pharmacological management.

\section{Case reports}

\section{Clinical assessment}

Three paranoid schizophrenia patients were referred by psychiatrists for TD satisfying the proposed diagnostic criteria by Adityanjee et al. ${ }^{2}$ All three patients were managed by the Movement Disorder Group, Division of Neurosurgery, Department of Surgery and Department of Medicine and Therapeutics, Prince of Wales Hospital, Hong Kong. Despite withdrawal of the antipsychotic responsible for the condition, and switching to second-generation 


\section{蒼白球深層腦部刺激術：一種治療遲發性肌張力 障礙華籍患者的有效方法}

\section{胡日明、陳達明、朱獻倫、楊漢明、陳然欣、區鐘云、}

鄭蓋民、劉嘉怡、榮潤國、莫仲棠、潘偉生

具有多巴胺受體拮抗劑的藥物（如第一代抗精神病藥物）會引發遲發 性肌張力障礙。高達 $2 \%$ 的患者會發生這種情況, 而停藥後只有 $10 \%$ 的 患者可以康復。研究證明深層腦部刺激術對原發性肌張力障礙有效, 而其對繼發性肌張力障礙的療效亦漸漸被認同。本文報告三例患有嚴 重藥物難治性遲發性肌張力障礙症的華籍精神分裂症患者。他們分別 接受了蒼白球深層腦部刺激術。接受治療前, 患者無法自理日常生 活, 其中兩名患者更須長期臥床。他們的Burke-Fahn-Marsden肌張力 障礙量表 (BFMDRS) 平均為61分（介乎44-80分）, 而全面肌張力 障礙量表（GDS）平均分為47（介平40-52分），並無出現與手術相 關的併發症。接受治療三個月後, 三名患者都可以回復自理能力, 亦 可獨立行走而母須協助。BFMDRS和GDS分別有 $77 \%$ 和 $66 \%$ 的改善。 使用歐洲五維健康量表視覺模擬評分進行生活質量評估, 結果顯示其 中兩名患者在接受治療三個月後平均改善了 $86 \%$ 。臨床跟進顯示效果 能維持三到十年。蒼白球深層腦部刺激術對於藥物難治性遲發性肌張 力障礙的患者來説, 是一種既安全又高效的治療方法。 medication, they all experienced progressive TD with severe disability. Their clinical details are outlined in Table 1. Investigations excluding other movement disorders included serum levels of ceruloplasmin, copper, thyroid-stimulating hormone, thyroxine as well as syphilis, and antinuclear antibody titres were either undetected or within normal limits. Magnetic resonance imaging of the brain was also unremarkable. For objective clinical evaluation video filming, the Burke-Fahn-Marsden Dystonia Rating Scale (BFMDRS) and the Global Dystonia Rating Scale (GDS) scores were documented before the procedure, at 1 week and 3 months postoperatively., Quality of life $(\mathrm{QoL})$ assessments were performed for two of the patients, preoperatively and 3 months postoperatively, using the Chinese-version validated EuroQoL-5 dimensions (EQ-5D) instrument. ${ }^{10}$ This instrument serves as a basis for comparing health outcomes using a basic 'common core' of health-related QoL characteristics. The dimensions covered were mobility, self-care, usual activities, pain/discomfort, and anxiety or depression. ${ }^{11}$ After targeted questioning of these five domains, the patient was required to report on a visual analogue scale (VAS) from a score of zero (worst imaginable health state) to 100 (best imaginable health state).

\section{Operative procedure}

We performed frame-based stereotaxy using the Leksell coordinate frame and multipurpose stereotactic arc system (Elekta AB, Stockholm, Sweden). The target was set at the ventroposterior part of GPi. The target coordinates were $19 \mathrm{~mm}$ lateral to the inter-commissural line (from the anterior commissure to the posterior commissure [AC-PC line]), $2 \mathrm{~mm}$ anterior to the mid-commissural point, and $4 \mathrm{~mm}$ inferior to the AC-PC line. The trajectory on the coronal view was 0 degree from the midsagittal plane. On sagittal view, it was 60 degrees from the AC-PC line.

The operation was performed under local anaesthesia for patients 1 and 2 in December 2004 and March 2009, respectively. Patient 3 was operated on under total intravenous general anaesthesia in April 2011 because of uncontrolled and vigorous trunk and limb movement. For patient 3, propofol was stopped 10 minutes before commencing microelectrode recording (MER). In all patients, MER was successfully performed and bilateral pallidal discharges were recorded.

For patients 1 and 2, visual-evoked MERs were registered at the target point by shining a light source in their eyes. If no capsular responses were evoked during macrostimulation below a threshold of $4 \mathrm{~mA}(0.1 \mathrm{~ms} \mathrm{PW}, 130 \mathrm{~Hz})$, a permanent quadripolar electrode (Medtronic 3387; Medtronic, Minneapolis [MN], US) was implanted bilaterally. During the same operative sitting, a pulse generator (Kinetra; Medtronic, Minneapolis [MN], US) was connected and implanted subcutaneously in the left infraclavicular region. A postoperative computed tomographic scan verified the final DBS electrode positions.

\section{Results}

Patients' mean age was 41 years, ranging from 28

TABLE I. Clinical characteristics of patients

\begin{tabular}{lcllcll}
\hline $\begin{array}{l}\text { Patient } \\
\text { No. }\end{array}$ & $\begin{array}{c}\text { Age } \\
\text { (years)/ } \\
\text { sex }\end{array}$ & $\begin{array}{l}\text { Psychiatric } \\
\text { disorders }\end{array}$ & $\begin{array}{l}\text { Offending } \\
\text { antipsychotic }\end{array}$ & $\begin{array}{c}\text { Exposure } \\
\text { duration } \\
\text { (years) }\end{array}$ & Affected body part(s) & Functional state \\
\hline 1 & $28 / \mathrm{F}$ & Schizophrenia & $\begin{array}{l}\text { Amisulpride } \\
\text { Quetiapine }\end{array}$ & 3 & $\begin{array}{l}\text { Head, face, neck, trunk, and limbs } \\
\text { (generalised) }\end{array}$ & $\begin{array}{l}\text { Dependent, bed-bound, and } \\
\text { with nasogastric tube feeding }\end{array}$ \\
\hline 2 & $46 / \mathrm{F}$ & Schizophrenia & $\begin{array}{l}\text { Haloperidol } \\
\text { Largactil }\end{array}$ & 2 & Head and neck (segmental) & Homebound with frequent falls \\
3 & $49 / \mathrm{M}$ & Schizophrenia & Fluanxol depot & 4 & $\begin{array}{l}\text { Head, face, neck, trunk, and limbs } \\
\text { (generalised) }\end{array}$ & $\begin{array}{l}\text { Dependent, bed-bound, and } \\
\text { with nasogastric tube feeding }\end{array}$ \\
\hline
\end{tabular}


TABLE 2. Stimulation settings and clinical outcomes

\begin{tabular}{|c|c|c|c|c|c|c|c|c|}
\hline \multirow{2}{*}{$\begin{array}{l}\text { Patient } \\
\text { No. }\end{array}$} & \multirow[t]{2}{*}{ Stimulation parameters } & \multicolumn{3}{|c|}{ BFMDRS } & \multicolumn{2}{|c|}{ GDS } & \multicolumn{2}{|c|}{ EQ-5D VAS } \\
\hline & & Pre-DBS & Post 1-week & $\begin{array}{l}\text { Post } \\
\text { 3-month }\end{array}$ & Pre-DBS & $\begin{array}{c}\text { Post } \\
\text { 3-month }\end{array}$ & Pre-DBS & $\begin{array}{l}\text { Post } \\
\text { 3-month }\end{array}$ \\
\hline 1 & $\begin{array}{l}\text { Monopolar case(+) 0(-)/4(-) } \\
3.9 \mathrm{~V}, \mathrm{PW} 210,180 \mathrm{~Hz}\end{array}$ & 58.5 & 40 & 14 & 50 & 21 & - & - \\
\hline 2 & $\begin{array}{l}\text { Monopolar case(+) 1(-)/5(-) } \\
3.9 \mathrm{~V}, \mathrm{PW} 120,130 \mathrm{~Hz}\end{array}$ & 44 & 1 & 0 & 40 & 0 & 50 & 80 \\
\hline 3 & $\begin{array}{l}\text { Monopolar case(+) 1(-)/5(-) } \\
3.5 \mathrm{~V}, \mathrm{PW} 90,180 \mathrm{~Hz}\end{array}$ & 80 & 51 & 37 & 52 & 31 & 40 & 85 \\
\hline
\end{tabular}

Abbreviations: BFMDRS = Burke-Fahn-Marsden Dystonia Rating Scale; DBS = deep brain stimulation; EQ-5DVAS = EuroQol-5 dimensions visual analogue scale; GDS = Global Dystonia Rating Scale; PW = pulse width

to 49 years with a mean duration of antipsychotic exposure of 3.7 years. Patients 2 and 3 received first-generation antipsychotics and patient 1 was administered second-generation medication. Preoperatively, all patients required either assisted living or was homebound. The craniospinal regions were the most seriously affected regions and all demonstrated opisthotonus and retrocollis. Chronic rhythmic neck hyperextension movements resulted in premature cervical spondylosis, and patients 1 and 3 required nasogastric tube feeding. At the time of surgery, all were unable to walk independently. The mean preoperative BFMDRS score was 61, ranging from 44 to 80 , and mean GDS score was 47 , ranging from 40 to 52 . There were no treatment-related complications and the procedure was well tolerated. As expected, there was no minimal response before stimulation but after pulse generator activation, marked amelioration of dystonic symptoms was observed. The stimulation settings were set at monopolar mode (anodal case and cathodal target contact) and are presented in Table 2. Notable improvement was found in patients 2 and 3 within the first week. In that week, the mean BFMDRS score decreased by over $30 \%$. By 3 months, all patients reached a stable state with a mean of $77 \%$ and $66 \%$ improvement in the BFMDRS and the GDS scores, respectively. Patients 1 and 3 overcame dysphagia to resume oral dietary intake and all patients were able to perform basic activities of daily living without assistance. No psychiatric side-effects were detected. Patients 2 and 3 experienced an improvement in QoL as reflected by a mean increase in the EQ-5D VAS score by $86 \%$ (Table 2 ).

\section{Discussion}

Tardive dystonia is an iatrogenic complication belonging to a group of DRA-induced movement disorders known as the tardive syndromes. Although it may co-exist with tardive dyskinesia, TD is a distinct condition with different epidemiology, clinical features, prognosis, and treatment outcome. ${ }^{3}$
Literature shows a higher prevalence of TD in men than in women, with a male-to-female ratio of $2.4: 1$, and a mean age of onset of 36 years. ${ }^{2}$ The firstgeneration antipsychotics such as chlorpromazine, flupenthixol, and haloperidol are the strongest aetiological factors although second-generation medications and antiemetics such as metoclopramide have also been implicated. ${ }^{1,2}$ Although the mean duration of medication exposure varies from 3.3 to 6.6 years, there does not appear to be a minimal 'safe' period and symptom onset can occur as early as within days or weeks. ${ }^{1}$

In this report, all patients fulfilled Adityanjee et al's diagnostic criteria ${ }^{2}$ for TD, namely, (1) chronic dystonia characterised by sustained, stereotypical involuntary muscle contractions or posture; (2) dystonia developing during or within 2 months' discontinuation of treatment with DRAs; (3) other secondary dystonias adequately ruled out, and (4) a negative family history for dystonia. The onset of symptoms is insidious initially, involving one body region and, typically, progressing to segmental, ie craniocervical, or generalised dystonia. Torticollis or retrocollis is characteristic of TD and chronic repetitive movements could result in spondylotic myelopathy or even fractures. ${ }^{12}$ Truncal involvement manifests as opisthotonus and, in the severest of cases, patients could become bed-bound, reduced to a state of dependency. ${ }^{2}$ In contrast to classic orobuccolingual tardive dyskinesia, TD is largely irreversible with $90 \%$ of patients failing to achieve remission at a mean follow-up of 6.6 years. ${ }^{13}$

The limitations of medical treatment reflect incomplete understanding of the complex pathophysiology of TD. Multiple theories have been proposed of which the most prominent describe postsynaptic dopamine receptor hypersensitivity, degeneration of striatal cholinergic neurons, and gamma-amino-butyric acid-containing neurons. ${ }^{13}$ In contrast, the success of pallidal DBS in the treatment of primary dystonias led to its adoption for secondary dystonias such as TD..$^{5-7,14,15}$ In this 
series we demonstrate a significant beneficial effect for medically refractory TD where rapid remarkable improvements in motor symptoms were observed within days without exacerbation of psychiatric symptoms. Our results are in agreement with other DBS outcome trials for TD. A systematic review of 17 studies involving 50 TD patients concluded that pallidal stimulation led to a mean improvement in BFMDRS scores by $77.5 \%$ (95\% confidence interval, $71.4 \%-83.3 \%){ }^{4}$ The motor benefits are sustainable with a documented duration of 41 months (range, 18-80 months). ${ }^{5,7,16}$ Long-term responses for 8 to 10 years have also been reported. ${ }^{6,17}$ Although most data were from case studies or small trials, our experience supports DBS as an effective and safe surgical treatment modality that can considerably improve QoL.

Involuntary dystonic movement imposes unique technical difficulties not only for obtaining preoperative brain scans of acceptable quality, but also for performing the actual surgery. Sedation or general anaesthesia may be needed for such procedures as was needed in our patient 3. Furthermore, correct choice of anaesthetic drug is critical for successful MER. For example, propofol was found to affect the recording quality of the subthalamic nucleus of Parkinson's disease patients. ${ }^{18}$ To overcome this interference, lower doses of propofol were used; these proved to be equally feasible to perform MER under general anaesthesia. ${ }^{19,20}$ Due to the relatively rapid offset action of intravenous propofol, after 10 minutes of cessation, we were able to observe the characteristic mean discharge frequencies of 20 to 40 $\mathrm{Hz}$ at the GPi target. The discharge pattern qualities were similar to those of the other two patients for whom the procedure was performed under local anaesthesia. Our experience demonstrates that in severely dystonic patients, total intravenous general anaesthesia with propofol can produce comparable clinical outcomes.

In 2014, patient 1 has received DBS for 10 years. In that period, she was capable of performing daily activities at home without assistance and was considered to have dystonia remission. However, when the pulse generator battery approached its end-of-life state, 2 years after implantation, segmental dystonia reappeared over the neck and hand regions. Her BFMDRS score rapidly rose from 0 to 23 within a week. The symptoms were relieved after battery replacement. The high voltage and pulse width requirements in GPi stimulation for TD can considerably shorten battery longevity (Kinetra; Medtronic) to an average of 2 years. The introduction of a non-invasive transcutaneous rechargeable battery system (Activa; Medtronic, Minneapolis [MN], US) with a 9-year life span is an improved solution to frequent replacements. Not only is it more cost-effective in terms of overall battery costs, but also reduces the number of surgical procedures. All three patients are currently implanted with this new device. The daily recharging process was convenient and non-disruptive, and the pulse generator performance was as effective as the non-rechargeable counterparts. With these encouraging results, we have continued to provide DBS as treatment for patients with refractory TD. Two more cases were treated in 2013 and 2014, respectively, with results as good as those in the three cases reported here.

\section{Conclusion}

Medically refractory TD is a disabling and essentially irreversible condition that can be successfully managed by pallidal DBS. There is a need to conduct multicentre trials to reliably assess and define appropriate selection criteria for DBS as a new therapeutic option. In our series, response to stimulation can be observed as soon as within 1 week. Our patients experienced remarkable alleviation of dystonia symptoms at 3 months enabling them to return to performing daily activities without assistance, with no additional psychiatric sideeffects. On clinical follow-up, the effect was well maintained for a period of 3 to 10 years.

\section{Acknowledgements}

The Oriental Daily News Charitable Fund, Oriental Press Group Limited subsidised the purchase of the implantable hardware devices.

\section{Declaration}

No conflicts of interests were declared by authors.

\section{References}

1. Burke RE, Fahn S, Jankovic J, et al. Tardive dystonia and inappropriate use of neuroleptic drugs. Lancet 1982;1:1299.

2. Adityanjee, Aderibigbe YA, Jampala VC, Mathews T. The current status of tardive dystonia. Biol Psychiatry 1999;45:715-30.

3. Kiriakakis V, Bhatia KP, Quinn NP, Marsden CD. The natural history of tardive dystonia. A long-term follow-up study of 107 cases. Brain 1998;121:2053-66.

4. Mentzel CL, Tenback DE, Tijssen MA, Visser-Vandewalle VE, van Harten PN. Efficacy and safety of deep brain stimulation in patients with medication-induced tardive dyskinesia and/or dystonia: a systematic review. J Clin Psychiatry 2012;73:1434-8.

5. Trottenberg T, Volkmann J, Deuschl G, et al. Treatment of severe tardive dystonia with pallidal deep brain stimulation. Neurology 2005;64:344-6.

6. Chang EF, Schrock LE, Starr PA, Ostrem JL. Longterm benefit sustained after bilateral pallidal deep brain stimulation in patients with refractory tardive dystonia. Stereotact Funct Neurosurg 2010;88:304-10.

7. Gruber D, Trottenberg T, Kivi A, et al. Long-term effects of pallidal deep brain stimulation in tardive dystonia. 
Neurology 2009;73:53-8.

8. Burke RE, Fahn S, Marsden CD, Bressman SB, Moskowitz C, Friedman J. Validity and reliability of a rating scale for the primary torsion dystonias. Neurology 1985;35:73-7.

9. Comella CL, Leurgans S, Wuu J, Stebbins GT, Chmura T; Dystonia Study Group. Rating scales for dystonia: a multicenter assessment. Mov Disord 2003;18:303-12.

10. Luo N, Chew LH, Fong KY, et al. Do English and Chinese EQ-5D versions demonstrate measurement equivalence? An exploratory study. Health Qual Life Outcomes 2003;1:7.

11. Pinto Prades JL. A European measure of health: the EuroQol [in Spanish]. Rev Enferm 1993;16:13-6.

12. Konrad C, Vollmer-Haase J, Gaubitz M, Nabavi DG, Reilmann R, Knecht S. Fracture of the odontoid process complicating tardive dystonia. Mov Disord 2004;19:983-5.

13. Margolese HC, Chouinard G, Kolivakis TT, Beauclair L, Miller R. Tardive dyskinesia in the era of typical and atypical antipsychotics. Part 1: pathophysiology and mechanisms of induction. Can J Psychiatry 2005;50:541-7.

14. Kupsch A, Benecke R, Müller J, et al. Pallidal deep-brain stimulation in primary generalized or segmental dystonia. N Engl J Med 2006;355:1978-90.
15. Vidailhet M, Jutras MF, Roze E, Grabli D. Deep brain stimulation for dystonia. Handb Clin Neurol 2013;116:16787.

16. Sako W, Goto S, Shimazu H, et al. Bilateral deep brain stimulation of the globus pallidus internus in tardive dystonia. Mov Disord 2008;23:1929-31.

17. Boulogne S, Danaila T, Polo G, Broussolle E, Thobois S. Relapse of tardive dystonia after globus pallidus deep-brain stimulation discontinuation. J Neurol 2014;261:1636-7.

18. Raz A, Eimerl D, Zaidel A, Bergman H, Israel Z. Propofol decreases neuronal population spiking activity in the subthalamic nucleus of Parkinsonian patients. Anesth Analg 2010;111:1285-9.

19. Pinsker MO, Volkmann J, Falk D, et al. Deep brain stimulation of the internal globus pallidus in dystonia: target localisation under general anaesthesia. Acta Neurochir (Wien) 2009;151:751-8.

20. Hertel F, Züchner M, Weimar I, et al. Implantation of electrodes for deep brain stimulation of the subthalamic nucleus in advanced Parkinson's disease with the aid of intraoperative microrecording under general anesthesia. Neurosurgery 2006;59:E1138; discussion E1138. 